\title{
DESIGN AND DEVELOPMENT OF BIOGAS FROM DOMESTIC WASTES POWERED GENERATOR FOR RURAL COMMUNITIES IN NIGERIA
}

\author{
Abba, M. O., Alor, M. O., Okafor, E. N. C. and Ilo, F. U.
} Electrical/Electronic Engineering Dept, Enugu State University of Science \& Technology

\begin{abstract}
Rise in energy need today due to the shortage of fossil fuel has led to research on alternative sources. Biogas has proved to be one among the best because of cost and ease of production. This study investigatespowering a $3.5 \mathrm{kVA}$ generator using biogas. The process of biogas production from anaerobic digestion of cassava peelings, poultry droppings and beans wasteswere shown. A $0.1 \mathrm{~m}^{3}$ capacity biogas digester wasused to carry out this study with proper seeding and charging in three batch combinations. Cassava peeling and poultry dropping generated the highest biogas of $0.035 \mathrm{~m}^{3} / \mathrm{kg} /$ day at a $\mathrm{pH}$ value of 7.3 on the $19^{\text {th }}$ day, with cheap production cost.
\end{abstract}

Keywords:Anaerobic Digestion, Biogas fuel, Renewable Energy, waste

\section{Introduction}

Energy is a basic component of any social development and economic development of any society. It is also the key for poverty elimination in Nigeria and any society [2]. Inadequate availability of modern energy is the bane of human development [7]. Petroleum products are going on extinction and the prices are on the increase. More thanhalf of the country's populace depend on firewood for processing agric products, cooking and heating [8]. Biogas is a mixture of colorless, flammable gas obtained by the anaerobic digestion of plant based organic waste material [1]. Biogas technology has the potential to enhance energy availability, create diversity such that conventional fuel would not be the only source of energy and natural eco-system would be safe guarded. It can be used in rural settings [5]. Biogas burn without leaving soot and it is renewable. The constituents of biogas are as follows, methane $\left(\mathrm{CH}_{4}\right)$, hydrogen sulphide, carbon dioxide $\left(\mathrm{CO}_{2}\right)$ and traces of other gases. These gases are products of anaerobic conditionsfrom bio-degradable materials. Biogastechnology is very common in countries like India, China, Pakistan, U.S.A and most European nations [6]. The major problem is adapting the existing engines to biogas technology. When this is achieved, food waste management, and high cost of food processing would be enhanced.

Controlled Anaerobic digestion is used in the methane generation and the process is normally carried out in anaerobic digesters in which oxygen is completely excluded while at the same time putting other parameters governing anaerobic digestion process under control. The stages of anaerobic respiration are glycolysis and fermentation. In glycolysis, the glucose molecule breakdown into two three carbon compound pyruvic acid. In second stage, the pyruvic acid undergoes incomplete oxidation that is, fermentation [3].

\section{Loading of the Organic Matter}

The higher the substrate concentration at any given time, the higher the organic loading rate. On the other hand, the higher the organic loading rate, at any given concentration of influent substrate, the lower the retention time. Organic loading is a function of concentration of 
influent substrate and the hydraulic retention time. Faster rate of waste stabilization, higher daily rate of biogas production and higher rate of volatile solids are achieved by high loading rate.

Loading rate should be maintained as uniformly as possible so that there would be uniform production of gas. It will also minimize the imbalance between the methanogenesis and acidogenesis.

\section{Mixing of the Substrate}

Biological activities are increased when fluids in digester are mixed to provide a uniform temperature and nutrient conditions throughout the digester and to allow for optimal interaction between microorganism and waste constituents.

Mixing can be performed in various way like recirculation of sludge, by mechanical draft tube, gas recirculation or turbine or propeller mixer. The $\mathrm{pH}$ is lowered by the production of organic acid in the second stage of $\mathrm{AD}$. $\mathrm{pH}$ can also be depressed by feeding large quantities of fresh substrates into the digester. These can be mitigated by good mixing inside the digester. [4].

Feedstock Preparation from Wastes

In this experiment, the batch formation of charging was used, and the capacity of the digester was fixed at $0.1 \mathrm{~m}^{3}$ (100 liters). The cassava peelings were dried under the sun. The poultry droppings were spread under the sun and dried too. Equally the beans waste comprising of the removed husk, broken beans and those that were attacked by the weevils were dried. The state of the waste determines the ratio of water to waste. If the waste is very dry, the water to waste ratio is increased because the dry waste will absorb much of the water. The waste used in the charging of the digester was not very dry. The ratio of water to solid (waste) chosen for the digester is 3:1. In achieving this, the following measurements were followed.

These three wastes were combined in the following manner and used for the batch operation charging of the digester.

- A combination of poultry droppings and beans waste

- A combination of poultry droppings and cassava peelings

- A combination of cassava peelings and beans waste,

- $9.38 \mathrm{~kg}$ of cassava peelings were measured out using a weighing scale

- $9.38 \mathrm{~kg}$ of poultry droppings were measured out using the balance.

- A mixture of these samples was formed with the measured values and gave $18.76 \mathrm{~kg}$.

- Applying the 3:1 ratio of water to waste gives

- $\mathrm{H}_{2} \mathrm{O}$ Waste(Cassava peelings +Poultry droppings)

- 3

- $56.28 \mathrm{~kg}$

1

- Volume allocation in the digester

- The total volume of the digester by design is $0.1 \mathrm{~m}^{3}$ (100 liters).

- The volume allocation for the first batch - batch A is shown below.

- Space left for the biogas to be generated $=25 \%$

- Space to be taken by waste $\quad=25 \%$

- Space left for water $=50 \%$

\section{RESULTS AND DISCUSSIONS FROM BIOGAS RESOURCES}

For seeding procedure, cow dung was chosen and more of it was used to increase the start up process. Theloading ratewas small at the starting up time. This was increased gradually, little by little to full loading as the digestion process was established. Mixing of the Substrate was done by recirculation of sludge, by mechanical draft tube, propeller mixer 3 periods of 
mixing per day, each lasting 1 hour. There was a regular monitoring of gas production, temperature, $\mathrm{pH}$, volatile acid content, alkalinity and gas composition of the digester.

Table 1: Daily gas generation by the 3 different waste categories under batch Digestion in liters

\begin{tabular}{|c|c|c|c|} 
Time(days) & $\begin{array}{c}\text { Poultry droppings \& } \\
\text { cassava peelings(litre) }\end{array}$ & $\begin{array}{c}\text { Poultry droppings \& } \\
\text { beans waste(litre }\end{array}$ & $\begin{array}{c}\text { Beans waste \&cassava } \\
\text { peelings \{litre) }\end{array}$ \\
\hline 0 & 0.0 & 0.0 & 0.0 \\
\hline 2 & 0.0 & 0.0 & 0.0 \\
\hline 4 & 0.0 & 0.0 & 0.0 \\
\hline 6 & 1.4 & 1.9 & 0.7 \\
\hline 8 & 2.4 & 3.3 & 1.2 \\
\hline 10 & 11.8 & 7.1 & 6.6 \\
\hline 12 & 18.8 & 8.9 & 8.9 \\
\hline 14 & 26.8 & 12.2 & 11.8 \\
\hline 16 & 34.8 & 17.9 & 23.5 \\
\hline 18 & 36.2 & 29.1 & 24.6 \\
\hline 20 & 33.8 & 28.2 & 27.7 \\
\hline 22 & 28.2 & 31.0 & 28.2 \\
\hline 24 & 29.6 & 28.2 & 24.0 \\
\hline
\end{tabular}

The following agricultural wastes combinations, poultry droppings and cassava peelings, poultry droppings and beans wastes, and beans wastes and cassava peelings yielded a minimum of $0.224 \mathrm{~m}^{3}, 0.168 \mathrm{~m}^{3}$, and $0.157 \mathrm{~m}^{3}$ respectively in 24 days. The graph depicting this table of the volume of gas produced by each of the three different categories of wastes poultry and cassava peelings, poultry droppings and beans waste, and cassava peelings and beans waste mixtures is shown in figure labove.

From the graph of gas production by each of the three different waste mixtures, it is seen that the mixture of poultry droppings and cassava peelings yielded the highest volume of gas of $0.0362 \mathrm{~m}^{3} / \mathrm{kg} /$ day on $18^{\text {th }}$ day. This was closely followed by the mixture of beans waste and cassava peelings at $0.0282 \mathrm{~m}^{3} / \mathrm{kg} /$ day volume. Contrary to expectation on the toxic effect of cyanide on the biogas production but in conformity with reports of other researchers the mixtures containing cassava peelings did far better than expected.

This biogas produced contained methane, carbon dioxide, carbon monoxide and other impurities. These impurities were later removed to get pure methane. Gas carburetor was fitted to the generator so that the produced biogas was used to power the $3.5 \mathrm{kVA}$ generator. 


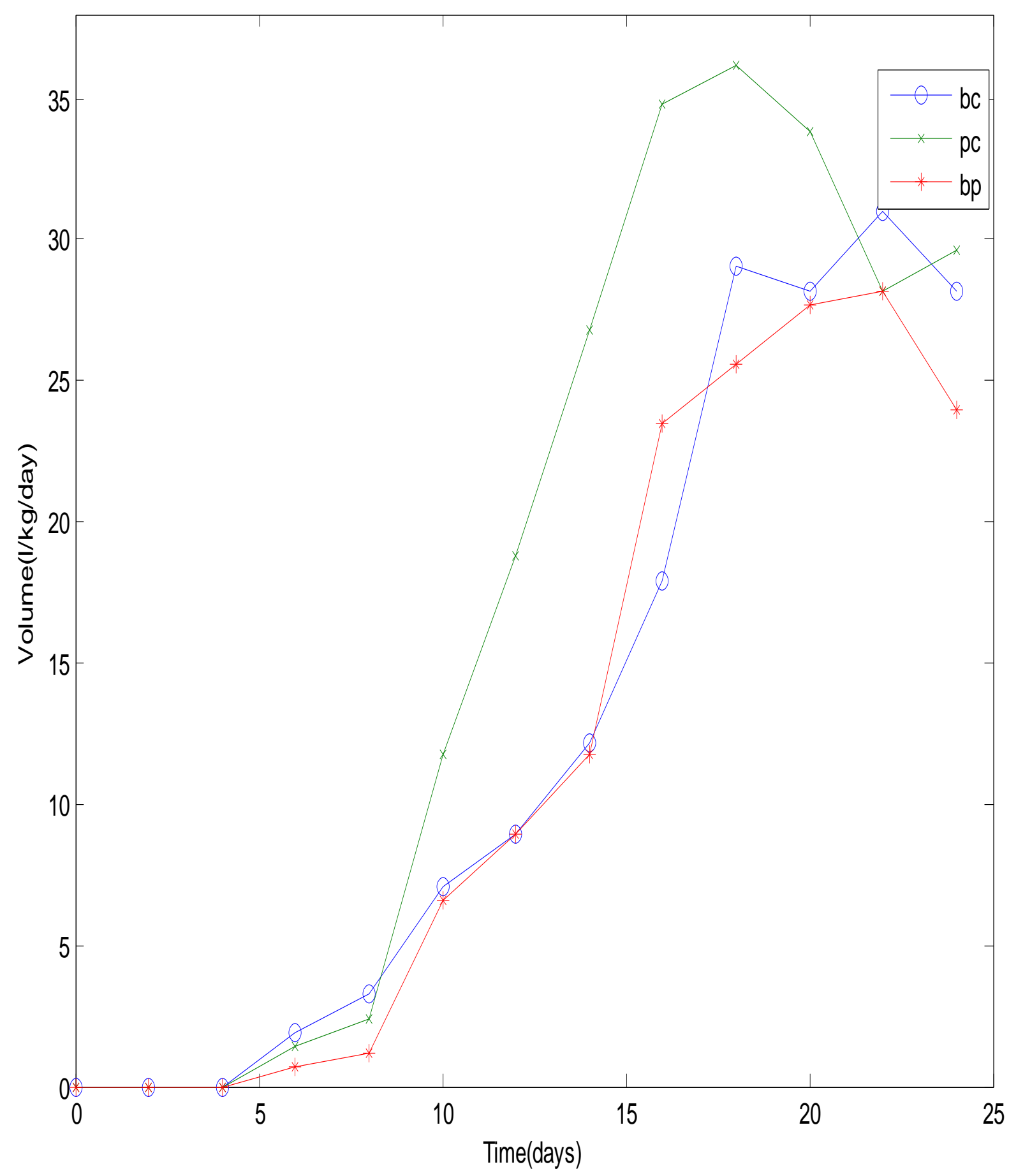

Figure 1: Daily gas yield during batch digestion of 3 categories of wastes. pc-poultry dropping and cassava peelings and water. bc-beans waste and cassava peelings and water. pbpoultry droppings and beans waste and water. 
From the graph of gas production by each of the three different waste mixtures, it is seen that the mixture of poultry droppings and cassava peelings yielded the highest volume of gas of $0.0362 \mathrm{~m}^{3} / \mathrm{kg} /$ day on $18^{\text {th }}$ day. This was closely followed by the mixture of beans waste and cassava peelings at $0.0282 \mathrm{~m}^{3} / \mathrm{kg} /$ day volume. Contrary to expectation on the toxic effect of cyanide on the biogas production but in conformity with reports of other researchers the mixtures containing cassava peelings did far better than expected.

This biogas produced contained methane, carbon dioxide, carbon monoxide and other impurities. These impurities were later removed to get pure methane. Gas carburetor was fitted to the generator so that the produced biogas was used to power the $3.5 \mathrm{kVA}$ generator.

\section{CONCLUSION}

The study of the digestion of a combination of poultry droppings and beans waste, a combination of poultry droppings and cassava peelings and a combination of cassava peelings and beans waste has shown that biogas can be produced from these wastes through anaerobic digestion for biogas production. The wastes are also readily available.

This biogas generated contained more than $80 \%$ methane which supports combustion and can be further processed to power generator. Finally the need to exploit this environmental friendly and cost effective renewable energy source will address the problem of cooking, drying, heating and cooling currently starring its ugly face on Nigerians. For rural settings to be able to get self sufficient through biogas technology is a major breakthrough in economic development of a nation.

\section{REFERENCES}

[1] Abubakar MM (1990) Biogas generation from animal wastes. Nigerian J Renewable Energy 5: 69-79.

[2] Aderemi, A.O., IIori, M. O., Aderemi, H. O. and Akinbami, J.F.K. (2009). Assessment off Electrical Energy use Efficiency in Nigeria food Industry. African J. of food sci. vol. 3(8) 206-216.

[3] Birendra Kumar (2017). Stages of Anaerobic Respiration. www.socratic.org (June, 2019)

[4] Craig C. and Gene S. (2017). Digester Mixing Fundamentals. BioCycle February 2017, vol.58, No.2, p.33

[5] Diaho, I.C., Tunga, U.S., and Umar, M.K (2005). Effect of abdominal waste on biogas production from cow dung. Bot. J. Tech. Vol. 14:21-24.

[6] Nwoke, O. O and Okonkwo, W. I (2006). Biogas Technology: A sustainable Energy and Waste Management option for rural development in Nigeria. Nigeria Journal of Solar Energy, 16:195-199

[7] Onafeso, O. D (2006). The need for Government ownership of solar energy production in the achievement of the millennium development goals in Nigeria. Nigeria Journal of Solar Energy, 16: 143-154

[8] Obasanjo,O.(2001).Nigeria Business Electricity Industry, Retrieved 12/12/2016 from http://nigeriabusinessinfo.com//energy.html. 